\title{
Makanan Tambahan untuk Balita dari Variasi Kacang Kedelai (Glycinemax (L) Merril) dan Kacang Merah (Vigna Angularis)
}

\author{
Dian Selistio $^{1}$, Nurhamidah ${ }^{1 *}$, Dezi Ilham ${ }^{1}$ \\ ${ }^{1}$ STIKES Perintis Padang \\ Jalan Adinegoro KM 17 Simpang Kalumpang Padang \\ *Email: nurhamidah_29@yahoo.com
}

\section{Article History}

Received: 15 Mei 2020

Reviewed: 2 Juni 2020

Published: 30 Juni 2020

Key Words

Soybeans, Kidney beans;

Oat snack bar;

Macronutrients;

Malnutrition.

\begin{abstract}
Malnutrition is a health problem that is a problem that must be resolved and needs special treatment. Handling malnutrition cases one which is by providing additional food in the form soy oat snack bars and kidney beans. The purpose of this study was to determine the effect of developing soybean and red bean oat snack bar. This research is an experimental research that is research with the substitution of soybeans and kidney beans then the effect is seen on the organoleptic quality with the SPSS test anova and seen its nutrient content in the laboratory of Unand. Research Results: 1) The highest organoleptic test is treatment A. 2) The oat snack bar produced the highest carbohydrate content in treatment A as much as $58.48 \%$, protein content $5.8 \%$, and calories 38.98 $\mathrm{kcal}$, the highest fat content in treatment $\mathrm{B}$ is $22.75 \%$, the highest water content in treatment $\mathrm{C}$ is $32.9 \%$. 3) The best formulation on oat soybean and red bean oat snack bars with several binding ingredients for color, taste, aroma, and texture as well as nutrients is treatment A (30 g soybeans: $50 \mathrm{~g}$ kidney beans). Development of Snack Bar Oat soybeans and kidney beans at Treatment A is an Oat Snack Bar has a high nutrient content and good color, taste, aroma, and texture.
\end{abstract}

\section{PENDAHULUAN}

Indonesia Negara kekurangan gizi nomor 5 di dunia. Peringkat kelima karena jumlah penduduk Indonesia juga di urutan empat terbesar dunia, jumlah balita yang kekurangan gizi di Indonesia saat ini sekitar 900 ribu jiwa. Jumlah tersebut merupakan 4,5 persen dari jumlah balita Indonesia, yakni 23 juta jiwa (Laksono, 2012). Masalah gizi buruk berdampak terhadap pertumbuhan, perkembangan intelektual, dan produktivitas, selain itu juga berdampak langsung tehadap kesakitan dan kematian (Supariasa, Bahri, \& Fajar, 2016).

Masalah gizi buruk merupakan masalah yang perlu dicegah dan perlu penanganan khusus. Penanganan khusus salah satunya berupa pemberian makanan tambahan terhadap penderita kekurangan gizi. Pertumbuhan balita dipengaruhi oleh kualitas makanan yang dikonsumsi sehari-hari, sementara kualitas makanannya tergantung pada pola asuh makan anak yang diterapkan dalam keluarga. 
Pemberian pangan fungsional tidak memberikan pengaruh terhadap status gizi subjek, namun terdapat kecendrungan meningkatkan kontribusi asupan zat gizi (Candra, Setiawan, Rizal, \& Damanik, 2014). Pengembangan pangan jajanan sangat penting karena pangan jajanan dapat dijadikan camilan sehari-hari dan rata-rata kontribusi energi dari konsumsi jajanan lebih dari 20\% (Hapsari, 2013). Maka perlu adanya penanganan masalah gizi buruk melalui pemanfaatan bahan baku yang lebih bervariasi contohnya seperti snack bar.

Snack bar merupakan makanan ringan yang berbentuk batangan berbahan dasar sereal atau kacang-kacangan. Selain makanan pokok, ketersediaan zat-zat gizi juga biasa berasal dari selingan/camilan (snack) (Sari, 2016). Sebagian besar penderita gizi buruk adalah anak-anak yang pada umumnya lebih menyukai cemilan dibandingkan makanan pokok seperti nasi.

Menurut (Wibowo, 2015) optimasi formulasi pembuatan snack bar kacang merahapel malang dengan penambahan tepung tempe dan kacang tanah mengandung kandungan gizi yang berimbang, yaitu: kadar karbohidrat $27,43 \%$, kadar protein $13,24 \%$, dan kadar lemak $22,81 \%$ dan disukai dalam hasil pengujian organoleptik berdasarkan atribut rasa dan kenampakan. Pembuatan snack bar variasi tepung beras merah dan kacang merah menunjukkan bahwa berpengaruh tidak nyata terhadap warna, aroma dan tesktur snack bar, tetapi berpengaruh sangat nyata terhadap rasa snack bar. Tujuan penelitian ini untuk mengetahui pengaruh pengembangan dari kombinasi Snack Bar Oat kacang kedelai dan kacang merah.

\section{METODE PENELITIAN}

Penelitian ini merupakan penelitian eksperimen murni yaitu penelitian dengan subtitusi kacang kedelai dan kacang merah dengan jumlah yang berbeda serta perlakuan yang berbeda yaitu: A (30 g kacang kedelai: 50 g kacang merah), B (50 g kacang kedelai: $30 \mathrm{~g}$ kacang merah), C (40 g kacang kedelai: $40 \mathrm{~g}$ kacang merah), kemudian dilihat pengaruhnya terhadap mutu organoleptik dan kadar zat gizi makronya. Uji organoleptik dilakukan di laboratorium Gizi kampus STIKes Perintis Padang dan Analisa zat gizi makro (karbohidrat, protein, lemak dan air) dilakukan di Laboratorium Unand (Universitas Andalas Padang).

Cara pembuatan Snack Bar Oat Kacang Kedelai dan Kacang Merah adalah sebagai berikut: Rebus kacang kedelai dan kacang merah selama 60 menit untuk menghilangkan rasa langu. Timbang kacang sesuai dengan berat yang telah ditetapkan. Blender hingga setengah hancur, Sebagai pengikat bahan dasar maka dilakukan pembuatan bahan pengikat seperti mencampurkan mentega, madu, kuning telur, gula dan selai kacang dengan takaran berbeda $(1: 2,2: 1,2: 2)$ pada masing-masing perlakuan, Selanjutnya campurkan kedua kacang dengan bahan pengikat yang telah dipisahkan berdasarkan perbandingan yang berbeda pada masing-masing perlakuan hingga tampak seperti gumpalan, masukkan kedalam loyang yang telah diberi kertas pemanggang. Oven pada suhu 1200C selama 60 menit. Setelah itu dinginkan dan potong adonan hingga berbentuk batangan.

\section{HASIL DAN PEMBAHASAN}

Hasil yang telah dilakukan dari uji organoleptik adalah sebagai berikut: 


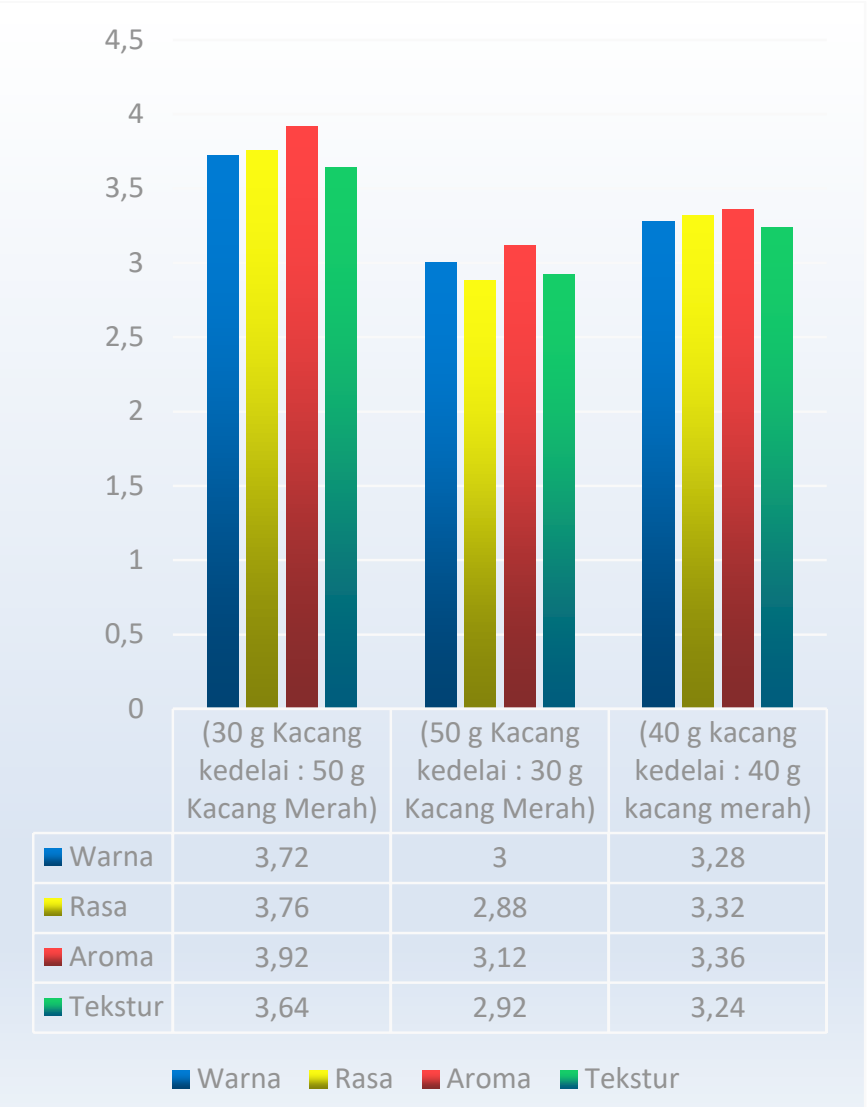

Gambar 1. Rata-rata Uji Kesukaan terhadap Snack Bar Oat Kacang Kedelai dan Kacang Merah

70

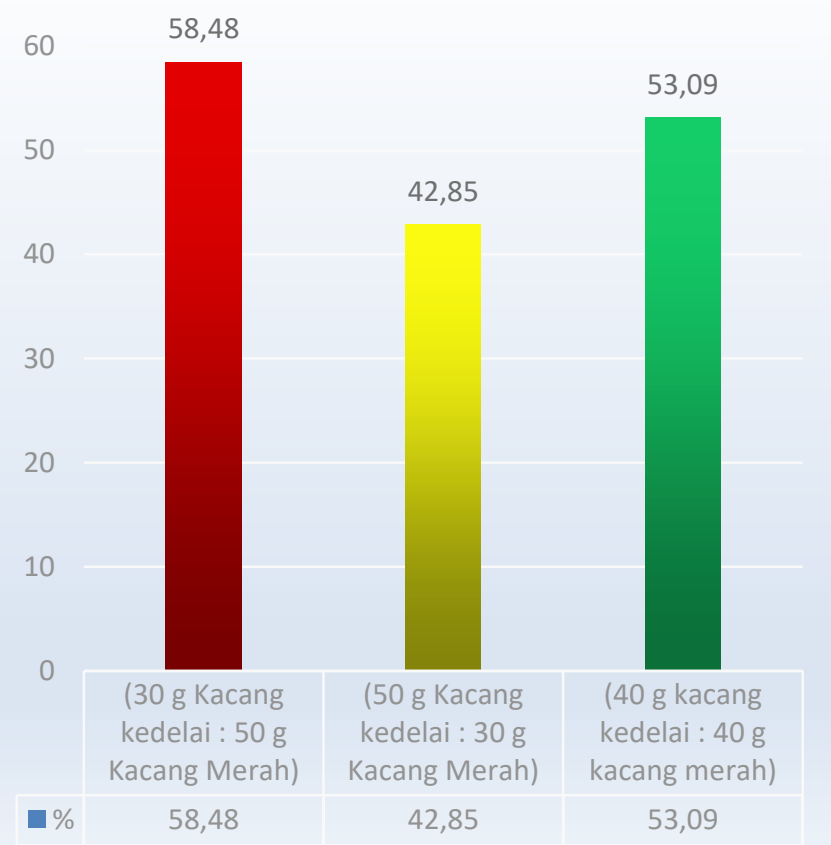

Gambar 2 Perbandingan Kadar Karbohidrat Snack Bar Oat Kacang Kedelai dan Kacang Merah 
Berdasarkan Gambar 1 dapat dilihat penilaian uji organoleptik Snack Bar Oat berbahan dasar Kacang Kedelai dan Kacang Merah memiliki hasil rata-rata perlakuan terbaik terdapat pada perlakuan A. Hal ini menunjukkan bahwa pembuatan Snack Bar Oat Kacang Kedelai dan Kacang Merah dengan nilai paling tinggi pada masing-masing indikator (warna, rasa, aroma dan tekstur) adalah perlakuan A (30 g kacang kedelai dan $50 \mathrm{~g}$ kacang merah) dengan hasil yang dibandingkan perlakuan B dan C

Kandungan Zat Gizi Snack Bar Oat Kacang Kedelai dan Kacang Merah adalah sebagai berikut (lihat Gambar 2). Pada Gambar 2 dapat dilihat bahwa karbohidrat pada sampel terbaik yaitu A 58,48\% sedangkan karbohidrat terendah pada perlakuan B yaitu $42,85 \%$.

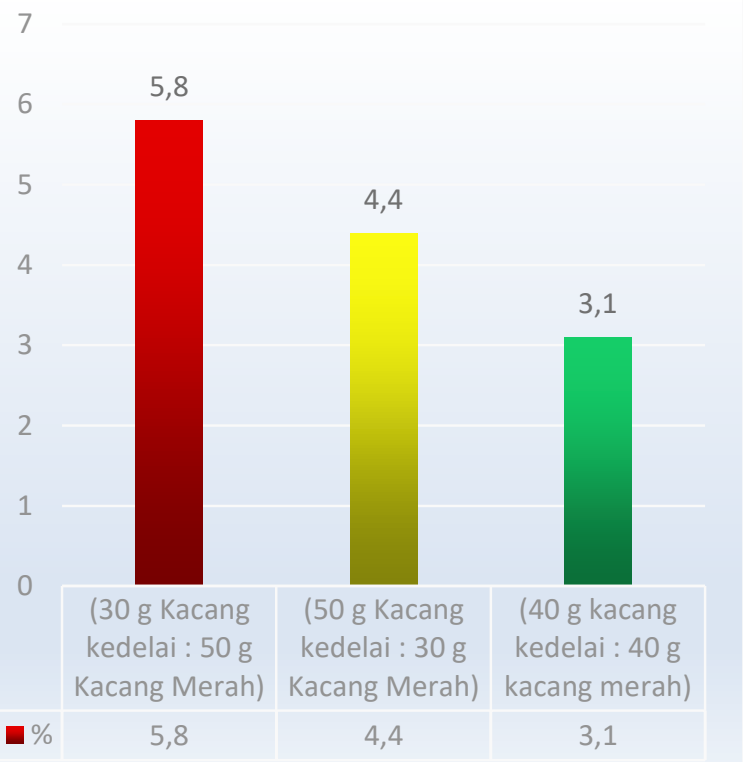

Gambar 3. Perbandingan Kadar Protein Snack Bar Oat Kacang Kedelai dan Kacang Merah

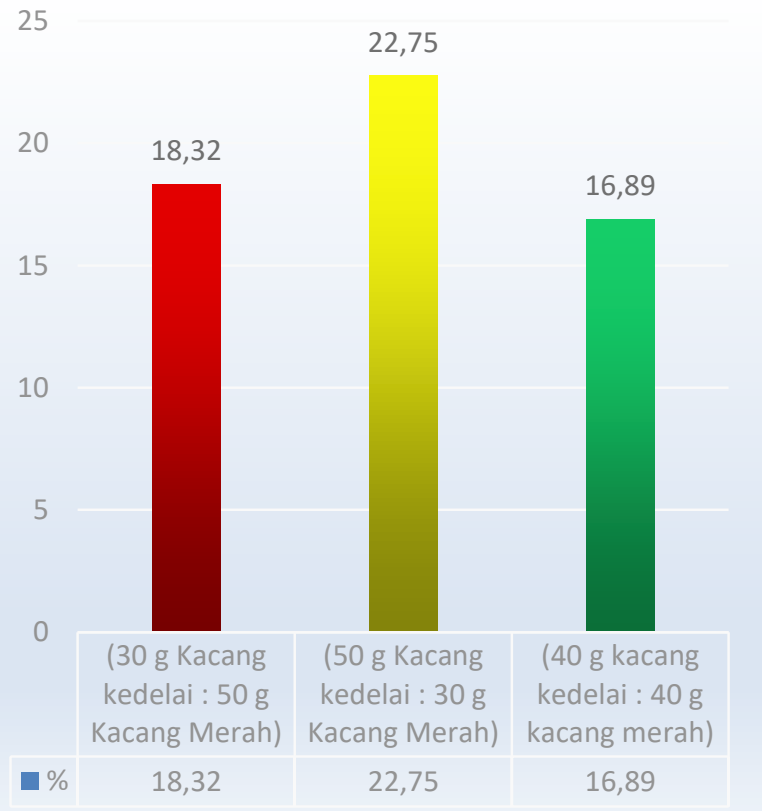

Gambar 4. Perbandingan Kadar Lemak Snack Bar Oat Kacang Kedelai dan Kacang Merah 
Pada Gambar 3 dapat dilihat bahwa Perlakuan A merupakan sampel terbaik dari uji organoleptik Snack Bar Oat Kacang Kedelai dan Kacang Merah. Protein pada sampel terbaik yaitu A 5,8\% sedangkan protein terendah pada perlakuan $\mathrm{C}$ yaitu $3,1 \%$.

Pada Gambar 4 dapat dilihat bahwa lemak Snack Bar Oat Kacang Kedelai dan Kacang Merah pada perlakuan B (50 g kacang kedelai dan 30 g kacang merah) lebih tinggi dibandingkan dari perlakuan A dan C. Lemak pada perlakuan B yaitu $22,75 \%$ sedangkan lemak terendah pada perlakuan C yaitu 16,89\%.

Pada Gambar 5 dapat dilihat bahwa kadar Air tertinggi pada sampel C yaitu 32,97\% sedangkan kadar air terendah pada perlakuan B yaitu $14,70 \%$.

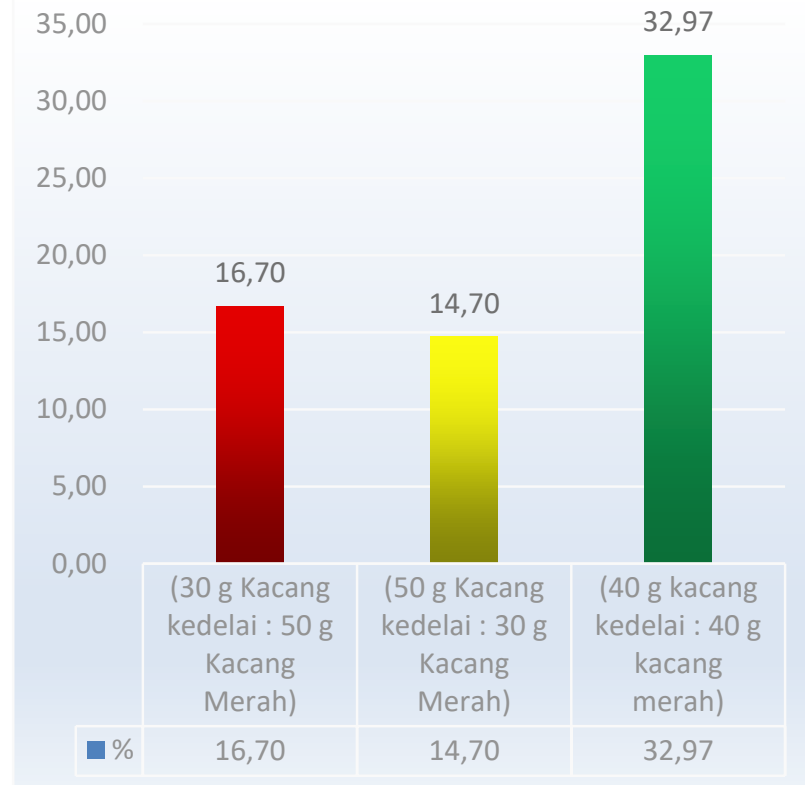

Gambar 5. Perbandingan Kadar Air Snack Bar Oat Kacang Kedelai dan Kacang Merah

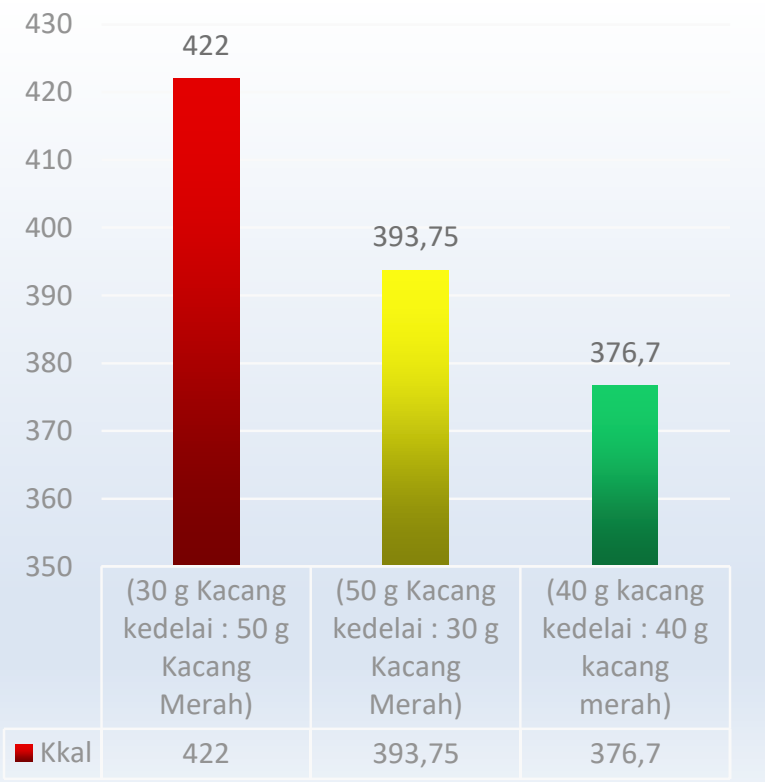

Gambar 6. Perbandingan Kalori Snack Bar Oat Kacang Kedelai dan Kacang Merah 
Kalori pada sampel terbaik yaitu A 422 kkal sedangkan kalori terendah pada perlakuan C yaitu 376,7 kkal. Dalam 8 g Snack Bar Oat Kacang Kedelai dan Kacang Merah mengandung kalori sebanyak 52,75 kkal. Satu potong Snack Bar Oat Kacang Kedelai dan Kacang Merah menyumbang kalori sebanyak $3,29 \%$. Formulasi terbaik dari segi organoleptik maupun dari kandungan zat gizi maka didapatkan adalah perlakuan A (30 g kacang kedelai dan $50 \mathrm{~g}$ kacang merah).

\section{Pembahasan}

Indikator penilaian adalah warna. Warna terbaik Snack Bar Oat Kacang Kedelai dan Kacang Merah adalah perlakuan A. Hal ini disebabkan karena perlakuan Snack Bar Oat Kacang Kedelai dan Kacang Merah dengan terlalu banyak kacang merah membuat Snack Bar Oat berwarna lebih gelap. Meskipun demikian warna gelap yang dihasilkan mempengaruhi kesukaan panelis karena faktor tekstur yang lebih renyah. Warna yang dihasilkan pada nutrimat bar formulasi P1 (100 : 0\% Kacang merah : kacang kedelai) lebih berwarna cokelat gelap dibandingkan dengan formulasi P5 (0:100\% kacang merah: kacang kedelai berwarna cokelat terang. (Wiranata, Puspaningrum, \& Kusumawati, 2017).

Indikator Kedua adalah rasa. Rasa terbaik Snack Bar Oat Kacang Kedelai dan Kacang Merah adalah perlakuan A yang disukai panelis. Dari ketiga perlakuan, perlakuan A terasa lebih gurih dan lebih manis. Rasa gurih yang dihasilkan berasal dari bahan dasar yang mengandung lebih banyak kacang merah yang mempunyai kandungan protein.

Indikator ketiga adalah aroma. Dari hasil penelitian aroma terbaik Snack Bar Oat Kacang Kedelai dan Kacang Merah adalah perlakuan A (30 g kacang kedelai dan $50 \mathrm{~g}$ kacang merah) yaitu agak harum dibanding perlakuan yang lebih banyak menggunakan kacang kedelai dimana masih terdapat bau langu dari kacang kedelai dan menjadi kurang disukai panelis. Hal ini berkaitan dengan penelitian (Wiranata et al., 2017) dimana aroma yang dihasilkan pada nutrimat bar perlakuan P5 lebih beraroma langu dibandingkan dengan perlakuan P2 oleh kerja enzim lipsigenase. Enzim bereaksi dengan lemak menggunakan air dingin hal inilah yang menyebabkan bau langu masih terasa saat meminum dan memakan produk olahan dari kacang kedelai.

Indikator penilaian keempat adalah tekstur. Dari hasil penelitian tekstur terbaik Snack Bar Oat Kacang Kedelai dan Kacang Merah adalah perlakuan A (30 g kacang kedelai dan $50 \mathrm{~g}$ kacang merah) yaitu lembut. Dalam hasil penelitian ini kadar air cukup tinggi dan peneliti tidak membandingkan kadar air dengan SNI. Kadar air yang tinggi mengindikasikan bahwa Snack Bar Oat kacang kedelai dan kacang merah memiliki kesegaran dan daya tahan yang rendah. Tidak tahan lama karena disebabkan mudahnya tumbuh mikroorganisme pada bahan yang memiliki kandungan air cukup tinggi yang dimiliki oleh Snack Bar Oat ini. Kadar air bahan pangan yang aman untuk penyimpanan adalah kurang dari $14 \%$ sehingga snack bar dengan kadar air rendah cukup mencegah pertumbuhan bakteri dan kapang (Septiani, Indrus, \& Wijaya, 2016).

Berdasarkan uji anova menunjukkan adanya pengaruh pengembangan kacang kedelai dan kacang merah warna, rasa, aroma dan tekstur pada snack bar oat.

\section{KESIMPULAN}

Pengembangan kacang kedelai dan kacang merah pada pembuatan snack bar oat menghasilkan kadar karbohidrat tertinggi pada perlakuan A sebanyak 58,48\%, kadar protein $5,8 \%$, dan kalori 38,98 kkal, kadar lemak tertinggi pada perlakuan B yaitu sebanyak 22,75\%, kadar air tertinggi pada perlakuan C yaitu 32,9\%. Formulasi terbaik pada Snack Bar Oat berbahan dasar kacang kedelai dan kacang merah dengan beberapa bahan pengikat untuk warna, rasa, aroma dan tekstur dan kandungan zat gizi adalah perlakuan A (30 g kacang kedelai : $50 \mathrm{~g}$ kacang merah).

\section{SARAN}

Snack Bar Oat direkomendasikan untuk anak balita adalah Snack Bar Oat dengan kandungan $30 \mathrm{~g}$ kacang kedelai dan $50 \mathrm{~g}$ kacang merah. Jumlah Snack Bar Oat yang dikonsumsi perhari adalah sebanyak 9-10 keping agar terpenuhi kebutuhan perhari baik protein, lemak maupun karbohidrat. Perlu adanya penelitian lanjutan untuk pemeriksaan 
zat gizi mikro pada Snack Bar Oat kacang kedelai dan kacang merah. Serta penelitian lanjutan untuk memaksimalkan daya tahan Snack Bar Oat agar bisa diproduksi dalam jangka waktu lama.

\section{DAFTAR KEPUSTAKAAN}

Candra, A. A., Setiawan, B., Rizal, M., \& Damanik, M. (2014). Pengaruh Pemberian Makanan Jajanan, Pendidikan Gizi dan Suplementasi Besa terhadap Status Gizi, Pengetahuan Gizi dan Status Anemia pada Siswa Sekolag Dasar. Jurnal Gizi Dan Pangan, 8(2), 103-108.

Hapsari, R. N. (2013). kontribusi makanan jajanan terhadap tingkat kecukupan asupan energi dan protein pada anak sekolah yang mendapat PMT-AS DI SD PLALAN 1 KOTA SURAKARTA. Surakarta, 1, 1-14.

Laksono, S. (2012). Status Gizi Siswa Kelas IV Sekolah Dasar Negeri Se-Gugus Sisingamangaraja Kecamatan Kertanegara Kabupaten Pubalingga. Universitas Negeri Yogyakarta.

Sari, S. M. (2016). Perbandingan Tepung
Sorgum, Tepung Sukun, dengan Kacang Tanah dan Jenis Gula terhadap Karakteristik Snack Bar. Universitas Pasundan.

Septiani, V., Indrus, J., \& Wijaya, H. (2016). Pembuatan Snack Bar Bebas Gluten dari Bahan Baku Tepung Mocaf dan Tepung Beras Pecah Kulit. Universitas Esa Unggul Jakarta.

Supariasa, I. D. N., Bahri, B., \& Fajar, I. (2016). Penilaian Status Gizi. EGC.

Wibowo, O. A. (2015). Optimasi Formulasi Pembuatan Snack Bar Kacang MerahApel Malang Dengan Menggunakan Program Linier.

Wiranata, I. G. A. G., Puspaningrum, D. H. D., \& Kusumawati, I. G. A. W. (2017). Formulasi dan karakteristik nutrimat bar berbasis tepung kacang kedelai (glycine max. L) dan tepung kacang merah (phaseolus vulgaris. L) sebagai makanan pasien kemoterapi. Jurnal Gizi Indonesia (The Indonesian Journal of Nutrition), $5(2)$,

133-139. https://doi.org/10.14710/jgi.5.2.133-139 